\title{
Resolving the Ineffability Paradox
}

\author{
Chien-hsing Ho
}

I

AQ: Please

If I believe that a certain item X is ineffable for the reason that X cannot be expressed ${ }_{\text {for each section }}^{\text {provide heading }}$ as it truly is by human concepts and words, questions arise as to how I can make this instead of known to others in words, how words can be used to gesture toward X. I cannot even numbered say $\mathrm{X}$ is unsayable, ${ }^{1}$ because in saying so, I would have made $\mathrm{X}$ sayable. This is a time- ${ }^{\text {head levels for }}$ honored conundrum known to many philosophers and religious thinkers in the East purpose. and the West. Confronting this conundrum, Augustine thinks it is better to evade the concerned verbal conflict silently than to quell it disputatiously, and early Wittgenstein famously asks us to pass over the ineffable in silence.

Indeed, a number of contemporary philosophers would agree that the unqualified statement " $\mathrm{X}$ is unspeakable" faces the danger of self-referential absurdity: if this statement is true, it must at the same time be false, given that $\mathrm{X}$ is speakable by the predicate word "unspeakable." This predicament can be formulated as the following argument, which I shall term the "ineffability paradox":

$\mathrm{P} 1: \mathrm{X}$ is unspeakable.

$\mathrm{P} 2$ : The statement " $\mathrm{X}$ is unspeakable" is true. (From P1)

P3: X is speakable by the predicate word "unspeakable." (From P2)

P4: The statement " $\mathrm{X}$ is unspeakable" is not true. (From P3)

$\therefore$ The statement " $\mathrm{X}$ is unspeakable" is both true and not true. (From P2 and P4)

Palpably, the conclusion of this argument is a contradiction. Recently, Graham Priest has reiterated that speaking of the ineffable does involve a real contradiction. However, his strategy for tackling something like the ineffability paradox, besides using the techniques of contemporary paraconsistent logic, is to aver that some contradictions are true in that they have their cause in the nature of reality, a nature that is contradictory. There are then, for Priest, contradictory statements that are true, and the statement " $\mathrm{X}$ is unspeakable" can well be both true and contradictory. ${ }^{3}$ Nevertheless, most of us would find it hard to swallow the idea of the contradictoriness of reality. Consequently, we need to come up with a different strategy for resolving the paradox. 
After the linguistic turn in the early twentieth century, with so much emphasis placed on the ubiquity and significance of language, the notion of ineffability may, for many philosophers, become somewhat obsolescent, perhaps something to be left to mystics and old school metaphysicians. Then, why do we need to bother with the notion? With all due respect to language, however, we must not think that language knows no limits, as we must not think we can capture the fresh gust of present actuality in the box of past convention. It is not true that each and every aspect of reality is speakable in the sense of being directly and properly expressible in words. If so, the notion of ineffability can still be of relevance to contemporary philosophizing.

To explain-in its use of general terms, such as "tree" and "squirrel," language operates in the realms of resemblance or commonness. It relies for its operation on the application of a general term to many particular objects that are held to be subsumed under the concept that corresponds to that term. For example, the word "tree" can be used, on the grounds of different trees' resemblance to one another, to refer to any one tree or all trees. Yet, features that are really specific to a particular tree qua tree do not fall within the semantic range of the word. It helps little to appeal to more specific words such as "maple" or "sugar maple," because they, as general terms, also function on the grounds of resemblance. Thus, such features can be so concrete, specific, and fine-grained that the tree evades complete linguistic determination, which must be abstract, generic, and coarse-grained. Given that words do not match the features, the tree is ineffable in at least some of its aspects. ${ }^{4}$

Furthermore, if one's repertoire of realities does not include universals and resemblances (more or less generic features that may be believed by others to inhere in things of the world), then concrete particulars such as maples and apples are wholly ineffable insofar as they are taken to be devoid of objective universals and real resemblances. Dignāga (c. 480-540 CE), a prominent Indian Buddhist epistemologist, basically takes such a stance. ${ }^{5}$ For him, universals and resemblances are conceptually constructed and imposed onto real particulars, which are, in themselves, beyond the grip of words and concepts. The point for us is that the notion of ineffability may even concern objects of sense perception.

Now, if concrete particulars are ineffable, how are we to use words to refer to them? In the fifth chapter of his magnum opus, the Pramānasamuccaya, Dignāga puts forth a semantic theory of meaning known as the apoha (exclusion) theory, according to which a nominal word functions by excluding objects other than its own referent. The meaning of the word "maple" would then be the exclusion of non-maples. Dignāga does not explicitly address the aforesaid conundrum. However, the Chinese Yogācāra thinker Kuiji (窺基, 632-682) applies the theory to tackle the conundrum. As a first step toward resolving the ineffability paradox, I shall in the next (second) section discuss Dignāga's and Kuiji's relevant views on the issue.

In section 3, I first cope with the predicament of setting a limit to language. Then, I attend to a few passages in the works of the two Chinese Mādhyamika philosophers, Sengzhao (僧肇, 374?-414) and Jizang (吉藏, 549-623), and of the fifth-century Hindu grammarian-philosopher Bhartrhari to reconstruct a strategy for showing how we can gesture toward the ineffable without making contradictions. A key notion here is that of indication as an indirect mode of expression, the mechanism 
and functioning of which will be clarified. In section 4, I contrast indication with description while introducing the notion of correctness in order to resolve the ineffability paradox. Thereafter, I discuss and dismiss three other approaches for tackling the conundrum as well as two likely objections against my strategy. Section 5 presents the conclusion.

Indian philosophers generally think that to apply a nominal word properly to a thing, a basis for the application is needed, that when one cognizes in a thing the basis for the application of a word, one is justified in using the word to refer to that thing. A universal inherent in a thing would for many serve as the basis: when I cognize in a tree the universal mapleness, I am justified in applying the word "maple" to that tree. Alternatively, some may hold that things of the same kind bear a family resemblance between them, which can well serve as the basis.

Dignāga repudiates the reality of universals and resemblances. ${ }^{6}$ Instead, he brings in apoha or exclusion of others as a substitute for universals. The exclusion is only a conceptual-semantic item, to be reckoned with whenever we use words, but in no way truly inherent in a particular. Presumably, for him, the basis for the application of the word "maple" to particular maples is not the universal mapleness, but the exclusion of things other than maples, in short, non-maples, such as pines, breadfruits, rabbits, squirrels, hills, rivers, and so forth. The exclusion of non-maples is what all the particular maples have in common, on the basis of which one can use the word to refer to them. Incidentally, we can also use the term apoha operationally by saying that the word "maple" functions by excluding non-maples or by differentiating the maples from other things.

For Dignāga, a nominal word directly and properly expresses exclusion of others qua its basis of application. However, he also takes the word to directly and properly express something else. To cite two relevant statements:

S1: A word says (āha) those things that are qualified by exclusion of others.

S2: The word "tree" ... presents its own object (svärtha) as possessing the feature of being a tree. Thus, the object of a word is a thing qualified by exclusion, but not merely exclusion.

The word "tree" conventionally expresses and refers to all particular trees; it may, given contextual factors, be used to refer to a given tree. One may take S1 to mean that the word says (viz., directly and properly expresses) particular trees by excluding non-trees. However, on account of the ineffability of particulars, the word cannot really say any particular tree or any of the latter's intrinsic features. In addition, the qualifier-qualificand distinction is for Dignāga conceptually constructed. Thus, a conceptually unqualified particular tree must be distinguished from the tree qualified by the exclusion of non-trees. Meanwhile, the own object of the word, as noted in S2, is a thing qualified by the exclusion of non-trees. The exclusion is conventionally none other than the generic feature of being a tree, which the thing is linguistically 
presented as possessing. In any case, the word "tree" directly and properly expresses a conceptually qualified, generic tree as well as the exclusion of non-trees.

As such a qualified generic something is what a word semantically refers to, it may be termed the "semantic referent." In contrast, the real particular concerned may be termed the "intended referent," because it is what the language user intends to refer to but has difficulty putting into words. Of course, under normal circumstances, no one would use the word "maple" to refer to a conceptual-semantic item as the semantic referent. Given the ineffability of a particular maple qua the intended referent, however, we need to reckon with a generic maple as an individual thing taken precisely as conceptually qualified by the exclusion of non-maples.

Intriguingly, before the time of Dignāga, ideas similar to the notion of apoha were present in Chinese Madhyamaka. Sengzhao asserts that, in Mahayana Buddhist scriptures, the use of the word "existent" (you 有) with respect to a thing is to show that the thing is not nonexistent, whereas that of the word "nonexistent" ( $w u$ 無) is to make explicit that the thing is not existent. ${ }^{8}$ The words function by differentiating their referents from what the referents are not, rather than denoting something definitively existent or nonexistent. However, the rationale behind the assertion differs from Dignāga's. It concerns Sengzhao's own Mādhyamika view, which he thinks is implied in the scriptures, that the myriad things are empty in the sense of being void of any determinate form or nature.

Although the apoha theory was set forth to explain how nominal words function given the ineffability of particulars, Dignāga did not explicitly address the conundrum of saying the unsayable. Yet, the Chinese Yogācāra thinker Kuiji does apply the theory to offer a noteworthy solution?:

A particular cannot be reached by word and speech. ... [Question:] If so, all real things being unspeakable, wouldn't it be inappropriate as well to speak the word "unspeakable"? [Answer:] The word is spoken in order to exclude the speakables. It is not meant that the word "unspeakable" matches the substances of things (fati 法體), for the latter are not [what one would take to be by the concept of] unspeakable.

The question posed is that if one uses the word "unspeakable" to speak of particulars as unspeakable, one would self-contradictorily make them speakable. To resolve the problem, Kuiji applies the apoha operation to the word "unspeakable." The word here does not really reach or speak of the unspeakable; it does not predicate of the latter the intrinsic property of being unspeakable. Instead, the word functions by excluding speakable items such as unreal universals. Meanwhile, Kuiji implies that we must distinguish between an unspeakable thing in itself and what we understand it to be by the concept of "unspeakable," a distinction that corresponds to that between intended referent and semantic referent.

Kuiji's ingenious solution is helpful, but it does not explain how words used can refer, or direct one's attention, to the ineffable. ${ }^{10}$ Elsewhere, he claims that nominal words both exclude and signify. ${ }^{11}$ We may clarify this terse claim by considering the view of his pupil Huizhao (惠沼, 650-714), who appears to think something 
like this: as the word, say, "maple" was formed and learned by people's perceiving particular maples in the past, although it mainly excludes non-maples, one can use it provisionally to refer to what one intends to signify, namely, particular maples. ${ }^{12}$ Presumably, both convention and causation play a role here. Still, this view does not explain the mechanism of linguistic reference, so it is far from being satisfactory.

\section{III}

In the preface to his Tractatus, Wittgenstein writes thus: "In order to be able to draw a limit to thought, we should have to find both sides of the limit thinkable (i.e., we should have to be able to think what cannot be thought)." ${ }^{13}$ Similarly, it may be said, to set a limit to language, we should have to find both sides of the limit sayable and so the unsayable would turn out to be sayable. We can understand this by considering an analogical example in actual life. In order to draw a line as a limit on any surface, our eyes would have to look at both sides of the line. Then, the two sides of the line are on a par, equally visible or cognizable to us; in this sense, the limit ceases to be a limit. However, there is a line or limit that is an exception to this: the horizon.

Suppose, on a countryside, someone asks me about the location of village $\mathrm{X}$, which is somewhere beyond our visible horizon. Although I can point out the roads to X, which we both can see, I can only point toward X, of which neither of us can have a glimpse, while saying something like "It is over there above the horizon." Clearly, X and the roads to $\mathrm{X}$, on the two sides of the horizon, are not equally cognized. Still, with the information conveyed, the person can roughly locate $\mathrm{X}$ and know how to reach it. Likewise, things on the near side of our semantic horizon (the limits to sayability) can be spoken of or described, whereas those on the far side can only be gestured toward or indicated. The sayable and the unsayable, on the two sides of the horizon, are surely different. Even though words cannot describe the unsayable, they can gesture toward it, locating it on the far side of a segment of the semantic horizon.

Gesturing toward is an indirect mode of expression, and so I am assuming that the ineffable is indirectly expressible. As far as I can tell, when an Eastern ineffabilist asserts that a certain item $\mathrm{X}$ is ineffable, he or she is mostly denying any conformity between words and X, but not X's indirect expressibility too. In this regard, we may attend to Sengzhao again ${ }^{14}$ :

As this [sagely mind] is nameless, it cannot be spoken of in words. Yet, though it cannot be spoken of in words, it cannot be transmitted without the use of words. Thus, the sages speak all day without having spoken.

Sengzhao clearly implies that though sagely mind is unspeakable, it is linguistically transmittable. Words can be used to transmit information about the mind and thereby indirectly express it. Meanwhile, the paradoxical expression "the sages speak all day without having spoken" presumably means that the sages do not use words to speak the unspeakable. The words used are provisional, ${ }^{15}$ indirectly expressive, and to be negated if one takes them to represent the unspeakable as it is. 
Elsewhere, Sengzhao explains why anything is said to be ineffable ${ }^{16}$ :

A speech arises from names, names arise because of forms (xiang 相), and a form arises owing to the mind's cognizing a form [in its object]. What is formless is nameless, what is nameless is speechless.

The term "form" is related to the Indian notion of the basis for the application of a word. If one conceptually cognizes a generic or coarse-grained form in an object, one can adequately apply the corresponding word to the object, and the object is deemed sayable. However, if the object is not endowed with any such cognizable form, as sagely mind is for Sengzhao, then, being formless, it is nameless and unsayable.

Now, if $\mathrm{X}$ is formless and unsayable, how can we use words to refer to it? Sengzhao suggests that words used to identify the unsayable are provisional external appellations. According to Jizang, all the Buddha's teachings "are similar in trying provisionally to apply names and forms to that which is nameless and formless, in order that sentient beings realize the speechless by means of speech." ${ }^{17}$ Then, to let others understand the formless and unsayable X, we should provisionally apply the word "unsayable" to it. For this provisional application, a provisional form as the basis is needed. The form can be the state of being unsayable, or simply unsayability, which is what the word directly and properly expresses. Although $\mathrm{X}$ is formless, we can conceive this form of unsayability and apply or superimpose it onto $\mathrm{X}$ such that one understands that $\mathrm{X}$ is unsayable.

Something like this can be rationally reconstructed from the following passage by the Hindu grammarian-philosopher Bhartrhari in his attempt to resolve the conundrum of saying the unsayable ${ }^{18}$ :

If a thing is said to be unsayable, someway or another or in all ways, by some words, then its state of being unsayable [i.e., its unsayability] is not denied by those words. Indeed, a doubt with regard to an object does not function toward the dubiousness attached [to that object] without giving up its own nature.

Suppose for some reason I am doubting someone, I do not simultaneously doubt her dubiousness. If, instead, I come to doubt her dubiousness, then she is made free from doubt and my doubt gives up its original nature of rendering her dubious. Likewise, we can thus construe the functioning of the word "unsayable" in the statement " $\mathrm{X}$ is unsayable." The word denies only X itself, but not X's unsayability; that is, the word conveys that $\mathrm{X}$ is not sayable, but not that X's unsayability is not sayable. To put it the other way, the word says only X's unsayability, but not X itself. Significantly, this unsayability is not an intrinsic feature or property of X. It is only provisionally conceived and does not really inhere in X. Yet, by being superimposed on X, it makes known that $\mathrm{X}$ is unsayable. As $\mathrm{X}$ is not said, it is not made sayable. As the unsayability is said, by being superimposed on $\mathrm{X}$, one comprehends the unsayability of $\mathrm{X}$. Thus, the purpose of making known that $\mathrm{X}$ is unsayable is achieved, without thereby making $\mathrm{X}$ sayable.

The notion of superimposition plays a key role here as it helps to relate that which is said to what is unsayable and show how words can be used to direct one's attention to the unsayable. On the one hand, the superimposition has the function of revealing, 
because the superimposed unsayability shows $\mathrm{X}$ to be unsayable. It performs the function of concealing on the other, for it covers up the real nature of X, which is not unsayable in the way we understand X through the concept of unsayability (recall the above quotation from Kuiji). Then, we need to negate the superimposition, taking it as simply a provisional application, not a real attribution. In the provisional use of the word "unsayable," we cognize the unsayable through the superimposition on it of unsayability and the negation of this superimposition. Without the superimposition nothing about the unsayable would be intimated; without the negation the unsayable may erroneously become sayable. ${ }^{19}$

Let us use the term "indicate" in this technical sense: the word "unsayable" says the form of unsayability and so, with the unsayability being superimposed on $\mathrm{X}$, indicates $\mathrm{X}$ such that one comprehends that $\mathrm{X}$ is unsayable. Hence, indication is an indirect mode of expression that consists of two phases: the saying phase and the imposition phase. An indicative expression can indirectly express the unsayable without actually saying it.

In respect of the word "unsayable," we have so far focused on the form of unsayability. Yet, our discussions on Dignāga's apoha theory suggest that the word also directly and properly expresses a generic something qualified by the unsayability. It is a qualified generic X qua the word's semantic referent. The semantic referent is then superimposed on the unsayable $\mathrm{X}$ qua the intended referent such that one knows $\mathrm{X}$ to be something unsayable. However, we can generally neglect this aspect of the functioning of a word. In addition, while we have been mainly concerned with a word in the context of a sentence, the mechanism of indication can, mutatis mutandis, be applied to a sentence as well, allowing us to speak of an indicative sentence or statement.

Finally, indication can broadly be regarded as a gestural language. It helps to reconstrue, and is reinforced by, the horizon simile. Here, my pointing gesture, as it were, tells the direction for reaching village $\mathrm{X}$. This direction is superimposed onto what lies beyond a segment of the horizon, the result of which is the rough location of the village. The location may need implicitly to be negated as it is not truly an intrinsic feature of the village. In any case, the point for us is that we can gesture toward the ineffable without making contradictions.

\section{IV}

It is widely thought in contemporary philosophy that human language has both cognitive (referential) and noncognitive (nonreferential) functions. In its cognitive function, language is meant primarily to convey information about, or express factual descriptions of, the world. In its noncognitive function, language is used not primarily to convey information but to make a request, give an order, elicit feelings, evoke experiences, and so forth. Yet, I think it is unconvincing to hold that language has only one cognitive function, that is, to describe objects or states of affairs. Suppose $\mathrm{X}$ is unspeakable and the statement " $\mathrm{X}$ is unspeakable" truly describes what the case is, namely, the state of affairs of X's being unspeakable. Then, as X can be spoken of by the statement, the statement is both true and not true. The ineffability paradox ensues! 
Indication as an indirect mode of expression is broadly cognitive in that it conveys information about its intended referent. Unlike a description, however, an indication is not meant to, and does not actually, match the referent. Since the notion of truth is often understood to imply a correspondence between language (words, propositions) and reality (objects, states of affairs), we should not take an indicative sentence to be a truth-bearer: it is not either true or false. However, not only can an indication meaningfully, informatively gesture toward something beyond our semantic horizon, but the information transmitted can be correct or otherwise (In showing where village $\mathrm{X}$ is, my pointing would be correct if I point in the right direction, incorrect if otherwise.). Therefore, I suggest that we, instead, speak of an indication as correct or incorrect, where the notion of correctness does not imply the aforesaid correspondence.

Now, recall the argument I termed the ineffability paradox. The argument embodies a legitimate logical paradox if we treat its premises as descriptive statements, which are all plausibly true. However, if we treat $\mathrm{P} 1$, " $\mathrm{X}$ is unspeakable," as an indicative statement, then, even if the statement " $\mathrm{X}$ is unspeakable" is correct, it is not true that the statement is true. Therefore, P2 is false. Consequently, the argument turns out to be fallacious and fails to be a legitimate paradox. We have thus resolved the ineffability paradox. The point, then, depends on whether we use the words of the statement indicatively or descriptively.

There are, of course, other possible ways of responding to the conundrum of saying the unsayable or the ineffability paradox. To keep this chapter focused, I shall briefly discuss only three approaches that are pertinent here. The first approach distinguishes first-order from second-order use of words and treats the word "unspeakable" in the above statement as a second-order word that refers to first-order words. For instance, two verses after the above-quoted passage Bhartrhari writes: "What functions as a signifier cannot be signified. That which expresses something else cannot in the same context be expressed." ${ }^{20}$ Thus, the word "unspeakable" functions to convey that $\mathrm{X}$ cannot be spoken of by any first-order words, the word not being one of them. It is a mistake, and goes against the language user's intention, to assert that the use of the word in respect of X would result in self-referential absurdity. Meanwhile, in the paradox argument, the statement " $\mathrm{X}$ is unspeakable" ought to be qualified one way in $\mathrm{P} 2$, another way in $\mathrm{P} 4$; when this is done, the argument is fallacious and the paradox ceases to arise. One problem with this approach is that it implies that $\mathrm{X}$ can be spoken of by the word "unspeakable." 21 This is a bit odd, and anyone who adopts the approach owes us an explanation as to why and how $\mathrm{X}$ is speakable by second-order words but unspeakable by first-order words (when both are human words).

For similar purposes, the anonymous Chinese Buddhist text Awakening of the Mahayana Faith (Dacheng qishen lun, 大乘起信論) introduces the phrase "using words to exclude words" (yin yan qian yan, 因言遣言) to contend that the term “suchness" (zhenru, 真如) is the ultimate term that one can appeal to for intimating the ineffable mind of suchness, and that the term serves the function of excluding all other terms. Unlike the former approach, however, even the term "suchness," the text suggests, is provisional and does not match the ineffable. The commentator and Huayan master Fazang (法藏, 643-712) gives an intriguing analogy. One shouts “Quiet!" in order to stop human noises. Without the shouting, the noises would not be stopped. Yet, if one, 
to make sure that the order is obeyed, shouts several times, then one makes noises oneself and fails to stop noises. Just as here one must not keep shouting, likewise, the term "suchness" needs to be excluded too. ${ }^{22}$ This points to the second approach concerned, in which one negates or unsays whatever one has said about the ineffable. Of the paradox argument, one who upholds the approach can challenge even P1 by saying something like "I don't mean to say X is unspeakable" or "X's being unspeakable is also unspeakable."

We already touched on this approach while explaining Sengzhao's expression "the sages speak all day without having spoken." It is partially implicit in the discussion on the notion of superimposition. Like Kuijis ingenious apoha solution, the approach has the advantage of refraining from making the unsayable sayable. Nonetheless, they are both deficient because they do not clearly explain how words can, one way or another, be related to the unsayable: without the relation, the words used are hardly better than meaningless sounds. By contrast, our strategy overcomes this problem by resorting to the notions of superimposition and of gesturing beyond the horizon.

The third approach, the dialetheist approach, radically differs from the first two. In their paper on contradictions in Buddhism, Graham Priest, Jay Garfield, and Yasuo Deguchi contend that certain Mahayana Buddhists are committed to the view that some contradictions are true and acceptable, and that modern developments in paraconsistent logics have shown that such a stance can be rational. According to them, for instance, some Buddhists describe certain things about an indescribable reality such that the indescribable is described. ${ }^{23}$ Then, the paradox argument would have the conclusion that the statement " $\mathrm{X}$ is unspeakable" is both true and contradictory, which they would say is rationally acceptable.

If the Buddhist simply means to transmit indirectly certain information about an indescribable reality, then, as we have seen, to state that the reality is indescribable is not to describe it. There is no irresoluble contradiction here. It is, instead, gesturing beyond our semantic horizon by telling something about the direction across the horizon. To the best of my knowledge, Mahayana Buddhist thinkers never explicitly assert that some contradictions are true. Whereas some Buddhists are keen on using paradoxical or figurative expressions, this usually has to do with the perceived limitations of descriptive language. As an additional note, Priest's claim that reality is contradictory in the sense that it is such as to render certain contradictory statements true squares poorly with the Chinese Mādhyamika position that reality is empty of any describable determinate structure. ${ }^{24} \mathrm{~A}$ contradiction is as determinate as a tautology. Correspondingly, to claim that reality is contradictory is to predicate of reality a determinate, though contradictory, structure describable in words or logical symbols. Yet, what if reality is indescribable and, somewhat like an amorphous lump, empty of any determinate structure? Perhaps, the idea of a contradictory reality fits better with a logically possible world, but not the concrete world of lived experience.

To complete this section, let me examine two likely objections against my strategy. First, some may object that I, like many others, have unnecessarily complicated the issue of referring to the ineffable. After all, one can use nominal words simply as proper names that designate and refer to the ineffable. Since few would take a proper name to have any conceptual meaning or content, the use of such names would not result 
in the aforesaid conundrum. Second, it may be charged that my strategy is based on the problematic assumption that the ineffable is indirectly expressible. In actual fact, the objector may say, some ineffabilists claim or imply that the ineffable is indirectly inexpressible as well. Thus, even if we rephrase P2 of the paradox argument as "The statement ' $\mathrm{X}$ is unspeakable' is correct" (where the word "unspeakable" implies indirect inexpressibility), the argument would still have the contradictory conclusion to the effect that the statement is both correct and not correct. Then, the strategy fails to resolve the ineffability paradox.

In responding to the first objection, we may appeal to William Alston's views against a tactic for resolving the predicament of referring to the ineffable. For Alston, although the word "God" in the statement "God is ineffable" may be regarded as a proper name not standing for any concept, we would not count anyone as understanding the statement if he or she is unable to use some identifying phrase, for example "the first cause" or "the father of Jesus Christ," to explain the word. Yet, any such phrase would constitute a characterization of God and so make God factually speakable. ${ }^{25}$ The use or understanding of a proper name thus presupposes a certain expressible knowledge of the object named, but this inevitably implies the expression of the so-called ineffable. In addition, we also wonder how anyone can use the word "unspeakable" in the statement "X is unspeakable" as a proper name at all. Hence, the issue cannot be resolved so easily as is believed by the objector.

I agree with the second objection that if the ineffable $\mathrm{X}$ is directly and indirectly inexpressible, then one cannot express it without making contradictions. When asked any question about $\mathrm{X}$, the ineffabilist cannot but remain in silence. To make matters worse, if remaining in silence counts as a body language, which in turn counts as a form of language, then one cannot even stay silent. ${ }^{26}$ There would be no escape from self-contradiction. Nonetheless, it is never my intention to defend such an ineffabilist. In addition, to my knowledge, no Eastern ineffabilist referred to above asserts that his ineffable $\mathrm{X}$ is indirectly inexpressible. Consequently, our assumption is not problematic, and the objection may simply miss its target.

\section{V}

We began this chapter with the time-honored linguistic-philosophical conundrum of saying the unsayable and the related ineffability paradox. For many, this issue is unresolvable, which casts doubts on the viability of the notion of ineffability. After examining the Buddhist semantic theory of apoha and an apoha solution to the issue, we resorted to certain Buddhist and non-Buddhist philosophical materials to rationally reconstruct a strategy for coping with the conundrum and, especially, resolving the paradox. By introducing the mode of expression termed "indication," together with the relevant notions of superimposition and of gesturing beyond the horizon, I wish to have shown that expressing the ineffable does not necessarily involve irresoluble

contradiction. It is also hoped that our philosophical exercise, unusual in conjoining Chinese Buddhism and Hindu philosophy, points to a constructive way forward for comparative philosophy. 
If our strategy is on the whole persuasive, if we cannot adequately capture the fresh gust of actuality in the box of convention, then philosophers may need to recognize the limitations of language and acknowledge the relevance of the notion of ineffability for contemporary philosophizing. Instead of belittling language, this recognition may induce one to value even more various possibly non-descriptive modes of expression such as metaphor, negation, paradox, indication, parable, poetic language, and so on. It might also prompt philosophers to attend more than is normal to the concrete, fine-grained, and tacit aspects of human life and experience, which have tended to be filtered out by abstract philosophical thinking.

\section{Notes}

1 In this chapter, the words "ineffable," "unsayable," and "unspeakable" are used interchangeably.

2 Cf. William Alston, "Ineffability," Philosophical Review 65, no. 4 (1956), pp. 506-22;

Keith E. Yandell, "Some Varieties of Ineffability," International Journal for Philosophy of Religion 6, no. 3 (1975), pp. 167-79; and Walter Terrence Stace, Mysticism and Philosophy (Los Angeles: Jeremy P. Tarcher, 1987). Correlatively, Plantinga contends that the "view that our concepts don't apply to God is fatally ensnared in selfreferential absurdity." See: Alvin Plantinga, Does God Have a Nature? (Milwaukee: Marquette University Press, 1980), p. 26.

3 Graham Priest, Beyond the Limits of Thought (Oxford: Oxford University Press, 2002), pp. 294-5; Graham Priest, "Speaking of the Ineffable ...," in Nothingness in Asian Philosophy, ed. JeeLoo Liu and Douglas L. Berger (New York: Routledge, 2014), pp. 91-103.

4 I understand the notion of ineffability somewhat broadly. An item is ineffable (viz., directly and properly inexpressible) if it or its texture does not conform to the semantic structure of any words one may use to denote or describe it. Roughly something like this nonconformity or mismatch between language and reality is behind many Eastern thinkers' assertion of ineffability.

5 It is disputable whether Dignāga's notion of particular (svalakṣana) covers such medium-sized objects as maples and apples. However, we can here neglect this technical issue.

6 Richard P. Hayes, Dignāga on the Interpretation of Signs (Dordrecht: Kluwer Academic Publishers, 1988), p. 246. For a recent exposition of Dignāga’s apoha theory, see: O. Pind, "Dignāga's Apoha Theory: Its Presuppositions and Main Theoretical Implications," in Apoha: Buddhist Nominalism and Human Cognition, ed. Mark Siderits, Tom Tillemans, and Arindam Chakrabarti (New York: Columbia University Press, 2011), pp. 64-83.

7 Hayes, Dignāga on the Interpretation of Signs, p. 308: "śabdo 'rthāntaranivrttivisísțtān eva bhāvān āha"; Pind, "Dignāga's Apoha Theory," p. 83: "vṛkṣaśabdo . . svārtham vṛkṣalakșanam pratyāyayati . . ., evam ca nivrttiviśiștam vastu śabdārthạ, na nivrttimätram." In this chapter, all translations from Sanskrit and Chinese are mine.

8 Zhaolun, T 45: 152c12-14, 159b11; cf. 151b13-15. All references taken from Taishō shinshū daizōkyō 大正新脩大藏經 (abbreviated as T). In CBETA Chinese Electronic Tripitaka Version April 2014. Taipei: Chinese Buddhist Electronic Text Association. 
9 Cheng weishi lun shuji, T 43: 288a21-b1: “言說不及是自相。. . . 若爾, 即一切 法不可言, 不可言言亦不稱理? 遮可言故, 言不可言; 非不可言即稱法體, 法體亦非不可言故.”

10 As Priest puts it, "If one wishes to explain why something is ineffable, one must refer to it and say something about it. To refer to something else, about which one can talk, is just to change the subject." See: Priest, "Speaking of the Ineffable ...," p. 98. It is surely not enough just to take the word "unspeakable" to exclude speakables.

11 Yinming ru zhengli lunshu, T 44: 138a26-28. This claim is to explain why, by uttering the word "fire," one would obtain fire, but not water, when the particulars of both fire and water are unspeakable.

12 Cheng weishi lun liaoyi deng, T 43: 716b9-14. See also Cheng weishi lun shuji, T 43: 296c15-17.

13 Ludwig Wittgenstein, Tractatus Logico-Philosophicus, translated by D. F. Pears and B. F. McGuinness (London: Routledge and Kegan Paul, 1963), p. 3.

14 Zhaolun, T 45: 153c24-26: “斯則無名之法, 故非言所能言也。言雖不能言, 然非 言無以傳, 是以聖人終日言而未嘗言也.”

15 The words are provisional in that they are used provisionally in the sense that they are not meant to say or match the intended referent and need to be negated, especially if one takes them to represent the way the referent truly is.

16 Zhaolun, T 45: 159b20-21: “夫言由名起, 名以相生, 相因可相。無相無名, 無名無說.” In Chinese Buddhism, the word “name” (ming 名) normally means a nominal word, but not a proper name.

17 Shengman baoku, T 37: 5b18-19: “同是無名相中強名相說, 欲令眾生因言 以悟無言也.” Also, Jingming xuanlun, T 38: 856b7-8.

18 Wilhelm Rau, ed., Bhartṛharis Vākyapadīya: Die Mūlakārikās nach den Handschriften herausgegeben und mit einem Päda-Index versehen (Wiesbaden: Franz Steiner, 1977), p. 120: "tathānyathà sarvathā ca yasyāvācyatvam ucyate, tatrāpi naiva sāvasthā taị śabdaih pratișidhyate. na hi samíayarūpe’rthe śeșatvena vyavasthite, avyudāse svarūpasya samśayonyah pravartate." Bharțhari’s notion of superimposition (adhyäropa, samäropa) can be found in Rau, Bhartrharis Väkyapadìya, pp. 123, 132.

19 For a related paper of mine that focuses on Bhartrhari's approach, see: Chien-hsing Ho, "Saying the Unsayable," Philosophy East and West 56, no. 3 (2006), pp. 409-27. To my knowledge, the Mādhyamika philosopher Candrakirti (c. 600-650) and the Hindu Vedantic philosopher Śankara (c. 788-820) have both employed the notion of superimposition to show how we can use words to refer to the ineffable. However, they did not elaborate further the way I have done.

20 Rau, Bhartṛharis Vākyapadīya, p. 120: "na ca vācakarūpena pravrttasyāsti vācyatā, pratipädyaì na tat tatra yenānyat pratipadyate." Before this verse, Bhartrhari states that if someone claims that "all what I say is false," the person does not intend to take this claim to be false. That Bhartrinari mentions such examples may indicate that our aforesaid strategy is a reconstruction rather than an interpretation of his proposed solution.

21 If, however, the word "unspeakable" refers solely to first-order words, not to X, then the problem would be similar to the one faced by Kuiji's apoha solution.

22 See Dacheng qishen lun yiji (大乘起信論義記), T 44: 252c11-253a2.

23 Yasuo Deguchi, Jay L. Garfield, and Graham Priest, "The Way of the Dialetheist: Contradictions in Buddhism," Philosophy East and West 58, no. 3 (2008), pp. 399-401. We have above mentioned Priest's strategy. 
24 For Sengzhao's position on the issue, see: C. Ho, "Emptiness as Subject-Object Unity: Sengzhao on the Way Things Truly Are," in Nothingness in Asian Philosophy, ed. JeeLoo Liu and Douglas L. Berger (New York: Routledge, 2014), pp. 104-18.

25 Alston, "Ineffability," pp. 511-17.

26 In the Vimalakìrtinirdeśa Sütra, when asked about his own way of transcending duality, unlike other Bodhisattvas around who spoke their views, Vimalakirti, the main character of the sutra, wisely remained silent. He was then praised for his sacred silence. Commenting on this narrative, Jizang remarks that while other Bodhisattvas provisionally applied names to show the nameless and formless, Vimalakirti provisionally applied the forms of silence to make explicit the nameless and formless. Then, Vimalakirti's silence is none other than a provisional bodily expression. See Jingming Xuanlun, T 38: 856b6-11.

\section{References}

Alston, W. (1956), "Ineffability," Philosophical Review, 65 (4), pp. 506-22.

Cheng weishi lun liaoyi deng 成唯識論了義燈 [A Lamp for Illuminating the Meaning of the Vijñaptimātratāsiddhi Śāstra]. By Huizhao. In T, vol. 43, no. 1832.

Cheng weishi lun shuji 成唯識論述記 [Commentary Notes on the Vijñaptimätratāsiddhi Śāstra]. By Kuiji. In T, vol. 43, no. 1830.

Dacheng qishen lun yiji 大乘起信論義記 [Notes on the Meaning of the Awakening of the Mahayana Faith]. By Fazang. In T, vol. 44, no. 1846.

Deguchi, Y., Garfield, J. L., and Priest, G. (2008), “The Way of the Dialetheist: Contradictions in Buddhism," Philosophy East and West, 58 (3), pp. 395-402.

Hayes, R. P. (1988), Dignagga on the Interpretation of Signs, Dordrecht: Kluwer Academic Publishers.

Ho, C.-H. (2006), "Saying the Unsayable," Philosophy East and West, 56 (3), pp. 409-27.

Ho, C.-H. (2014), "Emptiness as Subject-Object Unity: Sengzhao on the Way Things Truly Are," in JeeLoo Liu and Douglas L. Berger (eds), Nothingness in Asian Philosophy, New York: Routledge, pp. 104-118.

Jingming xuanlun 淨名玄論 [A Treatise on the Profound Teaching of Vimalakirti]. By Jizang. In $T$, vol. 38, no. 1780.

Pind, O. (2011), "Dignāga's Apoha Theory: Its Presuppositions and Main Theoretical Implications," in M. Siderits, T. Tillemans, and A. Chakrabarti (eds), Apoha: Buddhist Nominalism and Human Cognition, New York: Columbia University Press, pp. 64-83.

Plantinga, A. (1980), Does God Have a Nature? Milwaukee: Marquette University Press.

Priest, G. (2002), Beyond the Limits of Thought, Oxford: Oxford University Press.

Priest, G. (2014), "Speaking of the Ineffable ...," in J.-L. Liu and D. L. Berger (eds), Nothingness in Asian Philosophy, New York: Routledge, pp. 91-103.

Rau, W., ed. (1977), Bhartṛharis Väkyapadìya: Die Mūlakārikās nach den Handschriften herausgegeben und mit einem Päda-Index versehen, Wiesbaden: Franz Steiner.

Shengman baoku 勝鬘寶窟 [The Jewel Cave of the Śrimālā Sütra]. By Jizang. In T, vol. 37, no. 1744.

Stace, W. T. (1987), Mysticism and Philosophy, Los Angeles: Jeremy P. Tarcher.

Taishō shinshū daizōkyō 大正新脩大藏經 (abbreviated as T). In CBETA Chinese Electronic Tripitaka Version April 2014. Taipei: Chinese Buddhist Electronic Text Association. 
Wittgenstein, L. (1963), Tractatus Logico-Philosophicus, translated by D. F. Pears and B. F. McGuinness, London: Routledge and Kegan Paul.

Yandell, K. E. (1975), "Some Varieties of Ineffability," International Journal for Philosophy of Religion, 6 (3), pp. 167-79.

Yinming ru zhengli lunshu 因明入正理論疏 [A Commentary on the Nyāyapraveśa]. By Kuiji. In T, vol. 44, no. 1840.

Zhaolun 肇論 [The Treatise of Sengzhao]. By Sengzhao. In T, vol. 45, no. 1858. 